\title{
For mange eller for få innleggelser?
}

Hvorfor legger vi pasienter inn i sykehus? Et generelt svar er at de bør innlegges dersom sykehusoppholdet muliggjør behandlingstiltak som har betydning for deres overlevelse, symptomer eller funksjonsnivå, og dersom det kan gi en diagnostisk eller prognostisk avklaring som er relevant i deres kliniske situasjon. De samme begrunnelsene gjelder innleggelser fra sykehjem (1). Uheldig innleggelsespraksis kan arte seg enten ved at pasienter innlegges uten å ha nytte av det eller ved at pasienter som ville hatt nytte av innleggelse, ikke blir innlagt. Den første kategorien er gjenstand for mye omtale og en del forskning, om den andre råder stort sett taushet både i det politiske og i det akademiske rom. Én åpenbar forklaring er at det metodologisk er mye enklere å identifisere den første pasientgruppen enn den andre. Men en medvirkende grunn er nok også at det for tiden er umåtelig mye mer politisk korrekt å omtale de unødvendige innleggelsene enn de innleggelsene som burde vært iverksatt, men som ikke ble det.

Ikke dermed sagt at studier av potensielt unødvendige innleggelser ikke er viktige. Sebastian von Hofacker og medarbeidere publiserer i dette nummer av Tidsskriftet en interessant studie av pasienter som ble innlagt fra sykehjem i Bergen til Haraldsplass Diakonale Sykehus mindre enn 48 timer før døden inntraff (2). I løpet av en ettårsperiode identifiserte de 26 pasienter, hvorav om lag to tredeler ble vurdert til å kunne ha unngått innleggelse dersom sykehjemmene hadde hatt tilstrekkelig kompetanse og gode nok rutiner for palliativ behandling. Én av tre pasienter kom fra ett og samme sykehjem, men det angis ikke hvor stor andel av Bergens sykehjemssenger dette sykehjemmet har. Artikkelen har to viktige budskap, ett eksplisitt og ett implisitt.

Det første budskapet er at selv om det gjøres et godt arbeid mange steder, så er den medisinske kvaliteten i mange norske sykehjem fortsatt svak. Når døende sykehjemspasienter innlegges uten medisinske opplysninger, uten informasjon om kroniske sykdommer og funksjonsnivå, uten vurdering av behandlingsintensitet og åpenbart med utilstrekkelige palliative tiltak, gir det grunn til alvorlig bekymring for hva slags helsetjenester vi tilbyr samfunnets aller sykeste og mest sårbare. Det er enighet om nødvendigheten av et faglig løft for sykehjemsmedisinen, men synspunktene spriker når det gjelder hvilke tiltak som skal anvendes. Problemet er dels kvantitativt (for få leger og andre kvalifiserte helsearbeidere i forhold til pasienttallet), og dels kvalitativt (sviktende kompetanse og interesse). Det kvantitative problemet kunne enkelt vært løst gjennom forpliktende nasjonale bemanningsnormer - det første av løftene i Soria Moria-erklæringen som Stoltenberg 1-regjeringen løp ifra. I stedet har vi fått uforpliktende prat om kommunens ansvar for selv å finne ut av bemanningsbehovet. Det kvalitative problemet krever mer differensierte tiltak, hvorav ett kunne være å etablere en egen spesialitet i sykehjemsmedisin.

von Hofacker og medarbeideres andre hovedbudskap er at problemet med innleggelse av døende pasienter fra sykehjem kvantitativt sett er minimalt. I den undersøkte tidsperioden var det omtrent 10000 døgnopphold ved Haraldsplass Diakonale Sykehus. Døende pasienter innlagt fra sykehjem uten god grunn sto altså for mindre enn $2 \%$ av oppholdene. Det er ille for de pasientene som får sitt dødsleie i en ambulanse eller i sykehusets akuttmottak. Men belastningen på sykehuset er nærmest neglisjerbar. Dette står i skarp kontrast til f.eks. Samhandlingsmeldingens påstand om at én av sju sykehussenger er belagt med pasienter som ikke skulle vært der (3). Selvsagt kan unødvendige innleggelser også gjelde andre pasientgrupper enn de døende fra sykehjem. Men det er interessant å merke seg at når politikere og byråkrater skal forsvare Samhandlingsreformens ideer, er dette nettopp den ene pasientgruppen som holdes frem. Det andre kardinaleksemplet er den gamle som egentlig ikke er syk i det hele tatt, men som innlegges av sosiale grunner. Også dette problemets omfang er en myte (4).

Generelt er det lettere å vurdere om en innleggelse var unødvendig i ettertid - når all diagnostisk informasjon er tilgjengelig - enn på det tidspunktet innleggelsen fant sted. Dette i og for seg åpenbare forholdet er godt dokumentert i et norsk forskningsprosjekt, som også viste at bestrebelser på å unngå «unødvendige» innleggelser lett vil føre til stort helsetap (5). Likevel bruker Samhandlingsmeldingen selekterte deler av dette forskningsprosjektet i sin argumentasjon. Nytten av en innleggelse er enda vanskeligere å vurdere hos gamle og multisyke pasienter, fordi de i utstrakt grad reagerer med tap av funksjon (forvirring, falltendens, bevissthetssvekkelse) ved akutt somatisk sykdom. For helsepersonell med begrenset kunnskap vil disse pasientene derfor lett fremstå som håpløst syke og kanskje sågar døende selv om de har kurerbare akutte tilstander. Samhandlingsmeldingens forslag om kommunal medfinansiering av sykehustjenester til gamle medfører åpenbart en risiko for at flere pasienter som burde vært innlagt, ikke blir det, slik von Hofacker og medarbeidere påpeker (2).

Samhandlingsmeldingens (3) selektive og upålitelige omgang med medisinske fakta reiser påtrengende spørsmål om hva som er motivet. En nærliggende forklaring er at oppdraget har vært å gi skinn av faglig legitimitet til et politisk ønske om å bruke mindre ressurser på nyttige helsetjenester til samfunnets svakeste, og mer på andre typer goder til mer taleføre velgergrupper. von Hofacker og medarbeidere har $-\mathrm{i}$ tillegg til å beskrive en viktig pasientgruppe - indirekte gitt et bidrag til å avkle Samhandlingsmeldingen litt av dens retorikk. For det fortjener de dobbel takk.

Torgeir Bruun Wyller

t.b.wyller@medisin.uio.no

Torgeir Bruun Wyller, f. 1960, er spesialist i indremedisin og i geriatri, professor i geriatri ved Universitetet i Oslo og overlege ved Geriatrisk avdeling, Oslo universitetssykehus.

\section{Litteratur}

1. Ranhoff $A H$, Linnsund JM. Når skal sykehjemspasienter innlegges i sykehus? Tidsskr Nor Lægeforen 2005; 125: 13-4.

2. von Hofacker $S$, Naalsund P, Iversen GS et al. Akutte innleggelser fra sykehjem til sykehus i livets sluttfase. Tidsskr Nor Legeforen 2010; 130: 1721-4.

3. St.meld. nr. 47 (2008-2009). Samhandlingsreformen. Rett behandling - på rett sted - til rett tid

4. Rashidi F, Mowinckel P, Ranhoff AH. Severity of disease in patients admitted for acute care to a general hospital: age and gender differences. Aging Clin Exp Res, in press.

5. Eriksen BO, Førde OH, Kristiansen IS et al. Cost savings and health losses from reducing inappropriate admissions to a department of internal medicine. Int J Technol Assess Health Care 2000; 16: 1147-57. 